\title{
Achieving Nearly Zero Energy Multi-family Houses in Cyprus through Energy Refurbishments
}

\author{
D. K. Serghides ${ }^{1, *}$, S. D. Dimitriou ${ }^{1}$, M. Michaelidou ${ }^{2}$, M. Christofi ${ }^{2}$, M. Katafygiotou ${ }^{1}$ \\ ${ }^{1}$ The Cyprus Institute, Energy, Environment and Water Research Center, Cyprus \\ ${ }^{2}$ Department of Civil Engineering and Geomatics, Cyprus University of Technology, Cyprus
}

Copyright $\bigcirc 2017$ by authors, all rights reserved. Authors agree that this article remains permanently open access under the terms of the Creative Commons Attribution License 4.0 International License

\begin{abstract}
Residential buildings account for the $63 \%$ of the total energy consumption of the building stock. The existing residential building stock exceeds the number of newly built dwellings in most developed countries. Therefore, the energy efficient renovation of the existing housing stock is imperative in order to reduce the building energy consumption. For this reason, European Union ranked the improvement of the buildings' energy performance as a high priority in its research agenda. Following Europe's 20:20:20 objective, this case study investigates refurbishment scenarios in order to achieve Nearly Zero Energy Buildings (NZEBs) in Cyprus. The research focuses on the Multi-family House typology, as classified in the framework of the Intelligent Energy Europe EPISCOPE project and specifically on retrofitting a Multi-family building constructed after 2006. A representative Multi-family building from the corresponding residential building typology in Cyprus was chosen and modelled using the software interface of the official Simplified Building Energy Model tool (iSBEM_Cy) for issuing Energy Performance Certificates (EPC). The study investigates whether it is possible for such a building to reach the Nearly Zero Energy Building standards with the implementation of the national energy performance requirements and identifies the lurking obstacles and challenges through building simulations.
\end{abstract}

Keywords Energy Performance, Multi-family Housing, Nearly Zero Energy Buildings

\section{Introduction}

The built environment is not only the largest industrial sector in economic terms; it is also the largest in terms of resource flow [1]. The increasing energy demand already threatens the future of the planet; as researches show that $10 \%$ of the world population exploits $90 \%$ of energy resources [2]. European Union (EU), the second economy worldwide, while consuming one-fifth of the energy produced in the world, has only few stocks of energy resources [3]. Under this threat, the European Union aims to attain a more sustainable future and therefore focuses on the existing building stock by identifying the potential energy conservation of the building sector.

Residential buildings comprise the biggest segment of the EU's building stock, with a floor space of $75 \%$ and are responsible for $2 / 3$ of the sector's energy consumption [1]. While new constructions add at most $1 \%$ a year to the existing stock, the other $99 \%$ of buildings are already built and produce about $26 \%$ of the energy-use induced carbon emissions [4]. Taking into account that the expectation for the structural life of a building often exceeds 60 years while the envelope shows signs of obsolescence after only in 20 or 30 years [4], it is understandable that a building completed in 2010 will undergo refurbishment during the next 10 to 20 years. The improvement of the energy performance of the existing residential stock in every country is essential since the operational cost, the energy consumption and the carbon dioxide emissions are key concerns of Europe in order to achieve the EU 2020 goals.

The Energy Performance Building Directive (EPBD) established the 'Nearly Zero Energy Building' as the building target as from 2018 for all new publicly owned or occupied by public authorities, buildings, and from 2020 for all new privately owned buildings [5]. By setting these objectives, at the European level the NZEBs should be reality in the next couple years. The EU has set targets for 2020 , which aim at a $20 \%$ reduction in greenhouse gas emissions from 1990 levels. The intent is to raise the share of the European energy consumption produced from renewable resources by $20 \%$ and to improve energy efficiency by $20 \%$. In order to meet these targets, the EU emphasizes the need of national definitions for the Nearly Zero Energy Building "NZEB". Complying with the EU targets [6], Cyprus has published the Directive 366/2014 referring to the minimum national requirements concerning the NZEB building [7]. 
Besides this, two major challenges need to be met before full integration of the NZEB concept into national building codes and/or international standards. This includes the adaptation of a common and unambiguous definition and the development of a supporting methodology for computing the energy balance [8]. Furthermore, it is necessary to investigate the cost-effectiveness of the refurbishment scenarios for the existing residential buildings in order to set minimum national requirements and NZEB definition for the renovation processes and promote deep refurbishment, as the current trend of energy refurbishment (including new NZEB construction after 2020), is proven inadequate for reaching the national climate protection targets [9].

\section{Literature Review}

Multifamily buildings worldwide vary widely in terms of heating, ventilation, and air-conditioning (HVAC) and other relevant systems, as well as in terms of building age, size, tenant income, financing structures, ownership structures and other important factors that may affect their energy efficiency and the related decision-making. Although in Cyprus it is easier to assign the Multi Family Houses into broad sub-categories [10], which facilitate the decision-making process, there is no "one size fits all" approach to retrofitting the existing stock. Nonetheless, general guidelines towards the most effective refurbishment strategies for NZEB could be provided from various studies in the field, concerning the optimisation of the building envelope, the upgrading of the electromechanical systems and the utilisation of Renewable Energy Sources (RES).

When dealing with new constructions, there are many parameters to be addressed in order to achieve a sustainable and bioclimatic design, beginning from the site planning and continuing to the orientation and shape, layout and envelope of the building [11]; nevertheless, when a building is under refurbishment the main area of improvement is its envelope. Regarding the optimization of the buildings envelope, in a recent study Serghides and Georgakis investigated the energy performance of the building envelope in order to identify the optimum relationship of cost effectiveness and energy efficiency in the thermal performance of the buildings in the Mediterranean region. From this study it was concluded that the most effective solution for an improved building envelope thermal performance is provided by the combination of external insulation on the building envelope and with the increase of the internal mass, which in turn increase the thermal capacity of the structure [12].

The RES contribution towards NZEB is proven to be vital for the improvement of the energy performance of a building [13] and might even result to a positive energy building [14]. A combination of upgrading the electromechanical systems, refurbishing the external envelope and introducing RES in the building is the most effective approach. Furthermore, an individualized approach for each building taking into consideration its own particularities is necessary in order to reach an optimal solution [15].

Previous studies on the Cyprus housing stock investigated the impact of different refurbishment scenarios on the energy consumption of different typologies of dwellings, including old Multi Family House and the corresponding savings [16-21]. The studies demonstrated the high effectiveness of the insulation on initially uninsulated buildings, the unviability of further insulating the envelope and the high contribution of the PV systems in the reduction of the greenhouse gases.

\section{Methodology}

This study focuses on the conversion of an existing Multi-Family Building, representing one of the main residential typologies in Cyprus [22] (43.3\% of prevalence among the residential building stock), into a NZEB and it highlights the arising challenges. The impact on the energy conservation, most notably on the cooling demand and the cost-effectiveness of the national energy performance requirements is investigated, and new optimised scenarios are proposed.

According to the IEE Project TABULA and the ongoing IEE Project EPISCOPE [23], twelve residential building typologies were established as typical and representative of the national residential building stock in Cyprus [24]. These are classified according to their chronological period of construction and their architectural and constructional characteristics. There are three building typologies which consist of the Multi Family Houses (MFH), the Terrace Family Houses (TH) and the Single Family Houses (SFH). These are further divided into four different chronological periods, supported by the data collected from the Cyprus Statistical Service [23]. Each chronological division was defined based on the different constructional regulations and techniques that were applicable throughout the years, formulating the four distinctive chronological categories. These categories are the following; a) Before 1980, b) Between 1981 and 2006, c) Between 2007 and 2013 and d) After 2014. The divisions were also guided by the rapid growth of the construction industry in Cyprus, which occurred after 1980, by the adoption of the European Directive 2002/91/EC in 2007 and the amendment of the Directive 433/2013, which was enforced in the beginning of 2014. It is worth mentioning that before the entry of Cyprus in the European Union there was no energy related legislation for the building sector.

The vast majority of the Multi Family Houses in Cyprus is detached, especially the newer ones is not situated in the old town centers. This was a basic typological element which guided the building selection, as well as the space-related characteristics (number of floors, apartments floor area, number of bedrooms in each apartment etc.), which had to approach those of the typical Multi - Family House of the 3rd 
chronological period. The fenestration to wall ratio and the existence of specific architectural features, such as the pilotis, were taken into consideration as well for choosing the case study building.

In order to perform this investigation, the total building area, the heated living volume and the constructional characteristics of the building envelope were documented. The constructional characteristics of the roof, the wall, the floor slab, the structure and the openings were recorded and their U-values as well as their thermal capacity were calculated. When this study was contacted, due to the lack of available data, mainly concerning the installed electromechanical systems, certain assumptions were made (length and type of pipes, condition of systems and energy efficiency) [24].

Initially, the energy performance of the building was found for its existing state, by calculating the energy performance of each apartment individually, and the corresponding energy consumptions were calculated. The apartments were grouped by floor and the total energy consumption was found for the three floors. Subsequently a standard NZEB refurbishment scenario was applied, based on the Directive 366/2014. The energy efficiency and the cost viability for each refurbishment measure related to the building envelope elements' thermal performance was assessed separately, for three (3) apartments on different floors. Additional measures, not included in the prerequisites of the Directive 366/2014, were examined in terms of their energy efficiency and cost effectiveness. Based on the findings an optimized NZEB scenario was developed, oriented to improve the energy efficiency and cost effectiveness of the refurbishment. The investment cost associated with the NZEB refurbishment scenarios as well as the payback period, were based on the current market values. These were calculated with the official tool published by the Ministry of Energy, Commerce, Industry and Tourism of Cyprus for the cost optimal energy conservation measures [25], in order to include the purchase, installation and construction costs for all the systems used for these retrofitting scenarios. The modelling tool used throughout this study for the energy performance calculation is the iSBEM-Cy, which is the governmental software for the issuance of Energy Performance Certificates, [26]. This is the official governmental software in Cyprus used for the categorization of energy efficiency in buildings and the calculation of $\mathrm{CO}_{2}$ emissions according to the European Directive 2002/91/EC [27].

\section{Case Study}

\subsection{The Building - General Information}

The case study concerns a 3-storied Multi-Family House (MFH) of 15 apartments with a Pilotis, a free, open space in the ground floor, used mainly as a parking space. It is situated in Aradippou, in the city of Larnaca, coastal area.
The block of flats was constructed in 2012 and is representative of its typology for the chronological period 2007-2014. The MFH was built after the launching of the Directive 568/2007 [23], thus having thermal insulation and double-glazed windows. Nonetheless, stricter Directives [7] are now in force and it is expected that deep renovation of the apartments, towards NZEB standards, will take place in the next 20 years. Therefore, identifying the most energy and cost effective refurbishment measures towards this directions, is necessary. The building under study is shown in Figure 1.

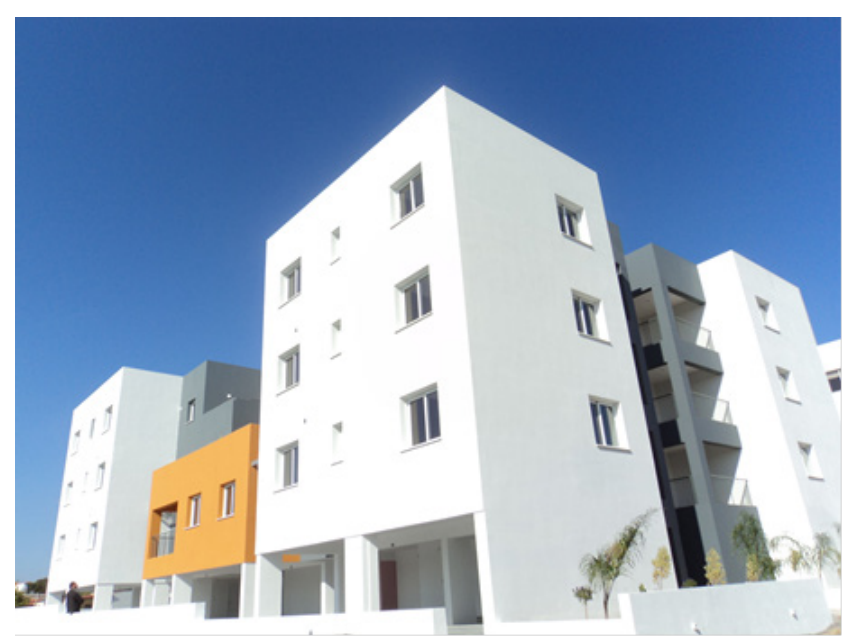

Figure 1. The Multi-Family House under study

The common spaces (staircases, elevators and corridors) are developed in such a way as to separate the apartments in Northeast oriented and southwest oriented ones. The usable heated living area and volume per floor is presented in Table 1 and the layout of the 3 floors in Figure 2.

Table 1. Existing Condition - Envelope Elements U-values

\begin{tabular}{|c|c|c|c|c|}
\hline \multirow{2}{*}{ Floor } & Volume & $\begin{array}{c}\text { Wall Area total/ } \\
\text { Fenestration }\end{array}$ & $\begin{array}{c}\text { Wall } \\
\text { area }\end{array}$ & $\begin{array}{c}\text { Exterior } \\
\text { Roof }\end{array}$ \\
\cline { 2 - 5 } & $\mathrm{m}^{3}$ & $\mathrm{~m}^{2}$ & $\mathrm{~m}^{2}$ & $\mathrm{~m}^{2}$ \\
\hline 1st & 481 & $481 / 57$ & 424 & 85 \\
\hline 2nd & 438 & $438 / 58$ & 381 & 85 \\
\hline 3rd & 439 & $439 / 58$ & 381 & 476 \\
\hline
\end{tabular}
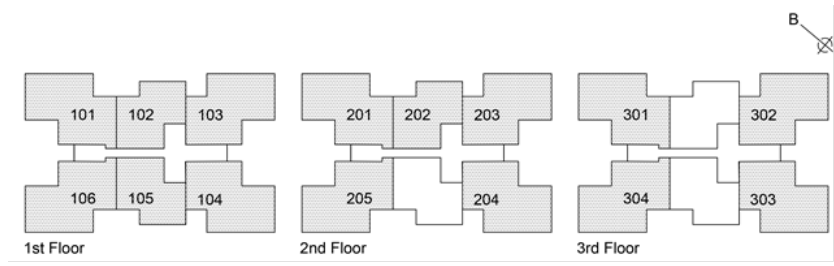

Figure 2. Floor and apartments' layout and orientation

\subsection{The Existing Condition of the Dwellings}

For the simulations each apartment is considered independently. For calculation purposes, the common wall between apartments is considered as adjacent to a non-heated space. Based on the calculation method used in iSBEM-Cy, the common spaces are considered heated. 
Table 2. Floor and apartments' layout and orientation

\begin{tabular}{|c|c|c|c|c|c|c|}
\hline Housing Unit Code & $\begin{array}{l}\text { Cooling } \\
\mathrm{kWh} / \mathrm{m}^{2}\end{array}$ & $\begin{array}{l}\text { Heating } \\
\mathrm{kWh} / \mathrm{m}^{2}\end{array}$ & $\begin{array}{c}\text { Mean } \\
\text { Consumption } \\
\text { per floor } \\
\mathrm{kWh} / \mathrm{m}^{2} \\
\end{array}$ & $\begin{array}{c}\text { RES Primary } \\
\text { Energy } \\
\mathrm{kWh} / \mathrm{m}^{2}\end{array}$ & $\begin{array}{c}\mathrm{CO}_{2} \text { emissions } \\
\mathrm{KgCO}_{2} / \mathrm{m}^{2}\end{array}$ & Energy Category \\
\hline 101 & 12.61 & 14.00 & \multirow{6}{*}{139} & 5 & 37.46 & $\mathrm{~B}+$ \\
\hline 102 & 5.62 & 11.05 & & 5 & 30.16 & $\mathrm{~B}+$ \\
\hline 103 & 5.48 & 15.60 & & 5 & 33.08 & $\mathrm{~B}+$ \\
\hline 104 & 13.93 & 13.59 & & 5 & 38.19 & $\mathrm{~B}+$ \\
\hline 105 & 38.19 & 6.53 & & 5 & 52.51 & $\mathrm{~B}+$ \\
\hline 106 & 25.11 & 11.28 & & 5 & 45.24 & $\mathrm{~B}+$ \\
\hline 201 & 4.61 & 18.15 & \multirow{5}{*}{124} & 5 & 34.41 & $\mathrm{~B}+$ \\
\hline 202 & 8.17 & 8.46 & & 5 & 30.13 & $\mathrm{~B}+$ \\
\hline 203 & 0.78 & 20.72 & & 5 & 33.41 & $\mathrm{~B}+$ \\
\hline 204 & 18.68 & 13.17 & & 5 & 41.00 & $\mathrm{~B}$ \\
\hline 205 & 14.34 & 11.40 & & 5 & 36.14 & $\mathrm{~B}+$ \\
\hline 301 & 16.94 & 8.96 & \multirow{4}{*}{146} & 5 & 36.13 & $\mathrm{~B}+$ \\
\hline 302 & 15.09 & 9.97 & & 5 & 35.46 & $\mathrm{~B}+$ \\
\hline 303 & 34.29 & 7.7 & & 5 & 48.90 & $\mathrm{~B}$ \\
\hline 304 & 31.01 & 6.80 & & 5 & 45.59 & $\mathrm{~B}+$ \\
\hline Average & 16.32 & 11.83 & & 5.00 & 38.52 & \\
\hline
\end{tabular}

The load-bearing structure of the building (beams and pillars) is made of reinforced concrete and the walls are of conventional brickwork, with plaster coating on both sides, resulting to a total thickness of $24 \mathrm{~cm}$. Double walls of total thickness of $30 \mathrm{~cm}$ separate the apartments. The windows are double-glazed with aluminum frame. The glazing area corresponds to a $5.0 \%$ of the total envelope area of the $1 \mathrm{st}$ floor, $11.0 \%$ of the $2 \mathrm{nd}$ and $6.4 \%$ of the $3 \mathrm{rd}$ floor. The roof is made of reinforced concrete and is horizontal. The concrete floor slabs of both floors are cladded with ceramic tiles of 2 $\mathrm{cm}$ thickness. External insulation (expanded polystyrene) of $3 \mathrm{~cm}$ is placed on the external walls, columns, beams, roof and pilotis, reaching the $\mathrm{U}$-values as required by the Directive 568/2007 [28] and as shown on Table 2.

For the study it was considered that all the apartments are using split-units for heating and cooling, installed in all the rooms, including the bathroom and the corridor. The Seasonal Energy Efficiency Ratio (SEER) and Seasonal Coefficient of Performance (SCOP) of the units are 5.1 and 3.4 respectively, corresponding to an A class system. All fifteen (15) apartments use solar thermal panels for Domestic Hot Water (DHW), backed up by an electric element.

After simulating each of the dwellings' energy performance using the iSBEM-Cy tool and afterwards grouping the apartments per floor, the mean calculated Total Primary Energy Consumption is $139 \mathrm{kWh} /\left(\mathrm{m}^{2} \mathrm{a}\right)$ for the first floor, $124 \mathrm{kWh} /\left(\mathrm{m}^{2} \mathrm{a}\right)$ for the second and $146 \mathrm{kWh} /\left(\mathrm{m}^{2} \mathrm{a}\right)$ for the third (Table 3 ). The Primary Energy Consumption is higher for the dwelling of the floors, which have large surface area exposed to the environment, compared with the apartment of the second floor. The $5 \mathrm{kWh} /\left(\mathrm{m}^{2} \mathrm{a}\right)$ of the Total
Primary Energy Consumption for each dwelling are produced from Renewable Energy Sources (RES), attributed to the solar thermal panels on the roof for DHW consumption for all the dwellings. Therefore, the renewable energy contribution in the total primary energy consumption ranges from $3.01 \%$ (Apartment 303) to 4.90\% (Apartment 202).

Table 3. Energy Consumption and $\mathrm{CO}_{2}$ emissions - Existing state

\begin{tabular}{|c|c|}
\hline Construction Element & U-value W/(m $\left.{ }^{2} \mathrm{k}\right)$ \\
\hline Horizontal roof & 0.654 \\
\hline External Walls & 0.581 \\
\hline Beams and columns & 0.758 \\
\hline Pilotis & 0.625 \\
\hline Double glazed windows & 3.60 \\
\hline
\end{tabular}

The corresponding energy consumption for heating ranges from $6.53 \mathrm{kWh} /\left(\mathrm{m}^{2} \mathrm{a}\right)$ to $20.72 \mathrm{kWh} /\left(\mathrm{m}^{2} \mathrm{a}\right)$, with the highest consumption observed in Northwest to Northeast oriented apartment 201 and Northeast to Southeast oriented apartment 203 of the 2 nd floor. Both their orientation and their exposed wall surface area lead to this elevated heating consumption. The highest cooling consumption is observed in the apartments 105 of the first floor and in the 303. The third floor, with consumptions of $38.19 \mathrm{kWh} /\left(\mathrm{m}^{2} \mathrm{a}\right)$ and 34.29 $\mathrm{kWh} /\left(\mathrm{m}^{2} \mathrm{a}\right)$ respectively. Both are mainly Southwest oriented and have exposed roof. The Energy Performance Certificate (EPC) Categorization reaches the class $\mathrm{B}+$ for all the apartments with the exception of 204 and 303, which reach the B class. 


\subsection{The Standard NZEB Refurbishment Scenario}

According to the Cyprus EPBD Directive 366/2014 [7] and in order to define a building as nearly Zero Energy one, specific U-values of the elements of the building envelope must be obtained and certain minimum energy performance requirements must be fulfilled, concerning the classification of the building, the total primary energy consumption, the energy demand for heating and the share of the contribution from the renewable energy sources in the total primary energy consumption. These requirements are shown on Table 4.

Table 4. NZEB minimum energy requirements

\begin{tabular}{|c|c|}
\hline \multicolumn{2}{|c|}{ NATIONAL NZEB REQUIREMENTS FOR HOUSES } \\
\hline $\begin{array}{c}\text { Technical specifications - Construction } \\
\text { Element }\end{array}$ & U-value W/(m² $\mathrm{K})$ \\
\hline Pitched roof with horizontal ceiling & 0.40 \\
\hline External walls & 0.40 \\
\hline Double glazed windows & 2.25 \\
\hline Energy Performance specifications & $\begin{array}{c}\text { Minimum } \\
\text { requirements }\end{array}$ \\
\hline Energy Performance Certificate & $\mathrm{A}$ \\
\hline Total Primary Energy consumption & $100 \mathrm{kWh} /\left(\mathrm{m}^{2} \mathrm{a}\right)$ \\
\hline Energy Demand for heating & $15 \mathrm{kWh} /\left(\mathrm{m}^{2} \mathrm{a}\right)$ \\
\hline $\begin{array}{c}\text { Renewable energy percentage of the total } \\
\text { primary energy consumption }\end{array}$ & $25 \%$ \\
\hline
\end{tabular}

In order to meet the minimum set requirements for the building envelope for the NZEB Directive, $30 \mathrm{~mm}$ of thermal insulation (expanded polystyrene) was added externally on the walls, the pilotis and the roof, reaching a total thickness of $60 \mathrm{~mm}$ and obtaining U-values $0.38 \mathrm{~W} /(\mathrm{m} 2 \mathrm{~K})$ for these elements. The windows were replaced with new, thermally improved ones, of lower U-value, $2.20 \mathrm{~W} /(\mathrm{m} 2 \mathrm{~K})$. Furthermore, 2 photovoltaic (PV) panels of total area of $3.2 \mathrm{~m}^{2}$ were placed on the roof of each dwelling with a south inclination of $30^{\circ}$. The existing AC units were substituted with ones of $\mathrm{A}+++$ class. The apartments with southeast and southwest oriented windows needed the addition of horizontal overhangs in order to reach the requirements.

\subsubsection{The NZEB Scenario Energy Performance}

Using the above energy conservation measures the energy performance of all the apartments was upgraded to A Category and met all the requirements of the NZEB definition for residential buildings under deep renovation [29].

As shown on Table 5, the calculated total primary energy consumption for the NZEB refurbishment scenario is reduced to $90 \mathrm{kWh} /\left(\mathrm{m}^{2} \mathrm{a}\right)$ for the first floor, $88 \mathrm{kWh} /\left(\mathrm{m}^{2} \mathrm{a}\right)$ for the second and $89 \mathrm{kWh} /\left(\mathrm{m}^{2} \mathrm{a}\right)$ for the third. The reductions in the total primary energy consumption per floor compared with their existing state are $35 \%, 29 \%$ and $39 \%$, for the 1st, the 2nd and the 3rd respectively. The contribution of Renewable Energy Sources (RES), including solar thermal panels for DHW and PV panels on the roof, was 27 $\mathrm{kWh} /\left(\mathrm{m}^{2} \mathrm{a}\right)$ for all the apartments, with the exception of the 3 smaller apartments (102, 105 and 202), which due to their size present higher contribution of RES per square meter of floor surface area. The RES cover $26 \%$ to $45 \%$ of the total primary energy consumption.

Table 5. Energy Consumption and $\mathrm{CO}_{2}$ emissions - Standard NZEB refurbishment

\begin{tabular}{|c|c|c|c|c|c|c|}
\hline Housing Unit Code & $\begin{array}{l}\text { Cooling } \\
\mathrm{kWh} / \mathrm{m}^{2}\end{array}$ & $\begin{array}{l}\text { Heating } \\
\mathrm{kWh} / \mathrm{m}^{2}\end{array}$ & $\begin{array}{c}\text { Mean } \\
\text { Consumption per } \\
\text { floor } \\
\mathrm{kWh} / \mathrm{m}^{2} \\
\end{array}$ & $\begin{array}{c}\text { RES Primary } \\
\text { Energy } \\
\mathrm{kWh} / \mathrm{m}^{2}\end{array}$ & $\begin{array}{c}\mathrm{CO}_{2} \text { emissions } \\
\mathrm{KgCO}_{2} / \mathrm{m}^{2}\end{array}$ & $\begin{array}{l}\text { Energy } \\
\text { Category }\end{array}$ \\
\hline 101 & 4.88 & 7.88 & \multirow{6}{*}{90} & 27 & 19.04 & A \\
\hline 102 & 1.58 & 6.71 & & 35 & 13.29 & A \\
\hline 103 & 1.47 & 8.99 & & 27 & 17.02 & A \\
\hline 104 & 3.45 & 7.78 & & 27 & 17.82 & A \\
\hline 105 & 11.65 & 2.94 & & 35 & 18.93 & A \\
\hline 106 & 7.07 & 7.03 & & 27 & 20.1 & $\mathrm{~A}$ \\
\hline 201 & 1.82 & 9.99 & \multirow{5}{*}{88} & 27 & 18.28 & A \\
\hline 202 & 2.5 & 4.82 & & 35 & 12.53 & A \\
\hline 203 & 0.16 & 11.01 & & 27 & 17.78 & A \\
\hline 204 & 8.81 & 7.18 & & 27 & 20.97 & A \\
\hline 205 & 6.5 & 5.94 & & 27 & 18.15 & A \\
\hline 301 & 6.71 & 4.31 & \multirow{4}{*}{89} & 27 & 16.91 & A \\
\hline 302 & 6.06 & 5.18 & & 27 & 17.09 & A \\
\hline 303 & 9.95 & 4.62 & & 27 & 19.73 & A \\
\hline 304 & 9.34 & 3.96 & & 27 & 18.73 & A \\
\hline Average & 5.46 & 6.56 & & 28.60 & 17.76 & \\
\hline
\end{tabular}




\subsubsection{The Payback Period}

For the calculation of the payback time the current market values were used, obtained from the suppliers of the materials and the systems used. The energy expenditure (in Euros) was also calculated based on the prices provided by the Cyprus Electricity Authority. In addition, an annual inflation of $3 \%$ on the electricity price was considered.

The payback period was estimated by floor, since agreement between all the owners of the first and third floor is necessary in order to refurbish the pilotis and the roof, respectively. The payback period for the first floor is calculated to be 50 years, for the second 25 and for the third 30 years. Therefore, the payback period marks the employed refurbishment measures as an unattractive option for the owners, who aim at a maximum payback period of 10 to 15 years. Thus, the refurbishment measures applied in this scenario were thoroughly investigated for three (3) apartments with the same orientation but on different floors, in order to conclude to their energy efficiency and their cost effectiveness.

\subsection{Impact of the Energy Conservation Measures and their Cost-Effectiveness}

The impact of each measure addressing energy performance of the building envelope upgrade was separately investigated for 3 apartments of the same orientation (Southeast to Southwest) in order to detect the most cost optimal ones. The measures investigated were the placement of insulation on the roof, the pilotis and the walls, the replacement of the windows, the installation of horizontal overhangs above the south facing windows, the replacement of the air-conditioning split-units with more efficient ones and the installment of photovoltaic systems. Each measure was investigated separately and its corresponding energy savings were calculated.

The highest energy savings for all 3 apartments are obtained through the AC upgrading, for A to A+++ class (with energy savings exceeding $1000 \mathrm{kWh} /$ year), followed by the installment of $2 \mathrm{PV}$ panels for the apartments of the first and second floor and by the placement of shading devices, of $1 \mathrm{~m}$ horizontal overhang, for the third floor apartment. Overall, the least energy conservation efficient measure is the replacement of double glazed windows with ones of lower U-value and the further insulation of the pilotis, with energy savings of 49 to $74 \mathrm{kWh} /$ year (Figure 2).

From the cost analysis it was concluded that the most cost - effective measure, for the three apartments studied, is the placement of horizontal overhangs in the Southeast and Southwest orientations, with 6 to 9 years for amortisation of the initial investment. The second most cost-effective measure is the installment of PVs with a payback time of 10 years (Figure 3). The remaining refurbishment measures studied (AC upgrading, Wall insulation, Windows replacement and Roof insulation) result to payback periods of 25 to 102 years and are therefore considered to be uneconomical as investments.

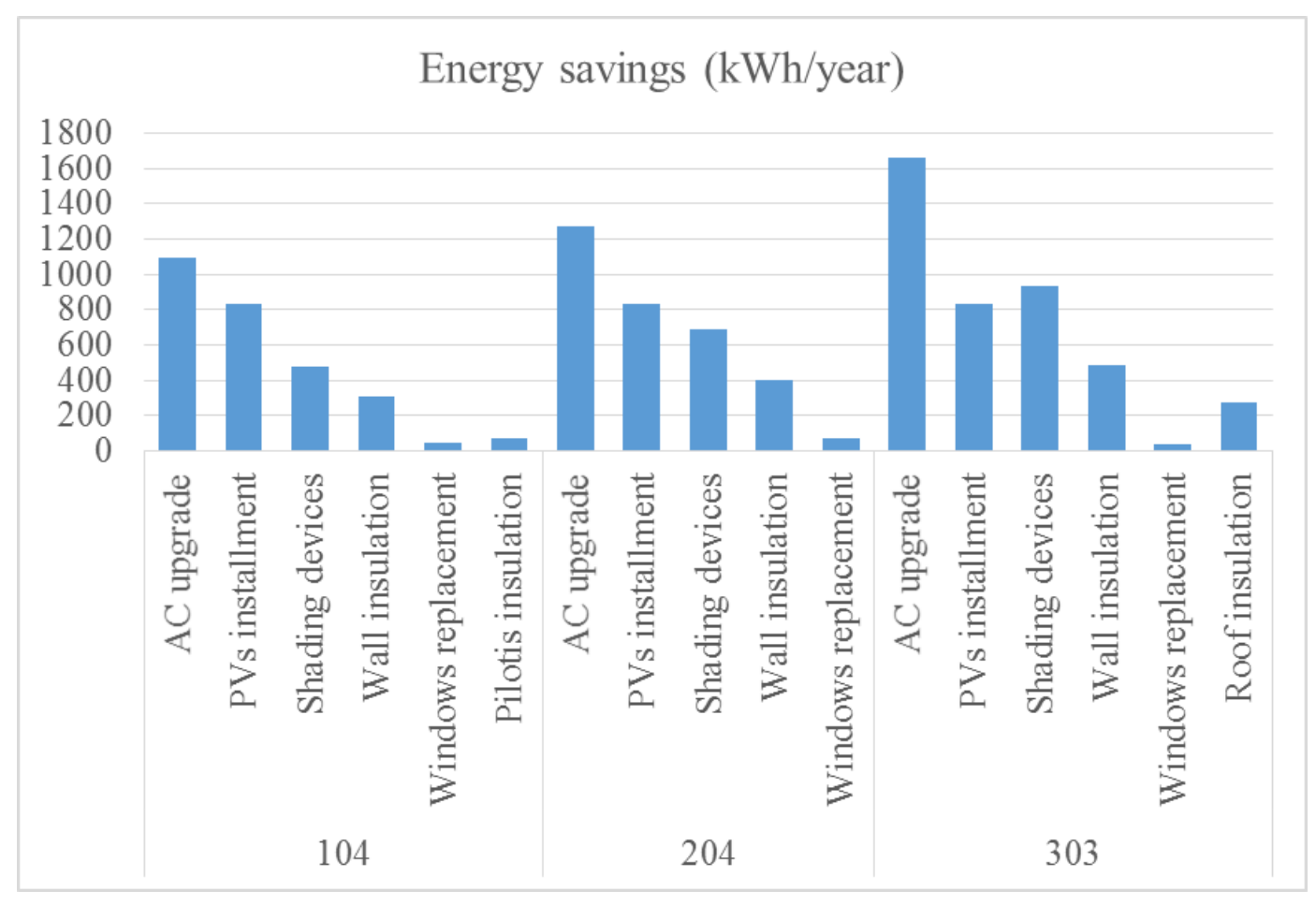

Figure 2. Energy Savings per refurbishment measures 


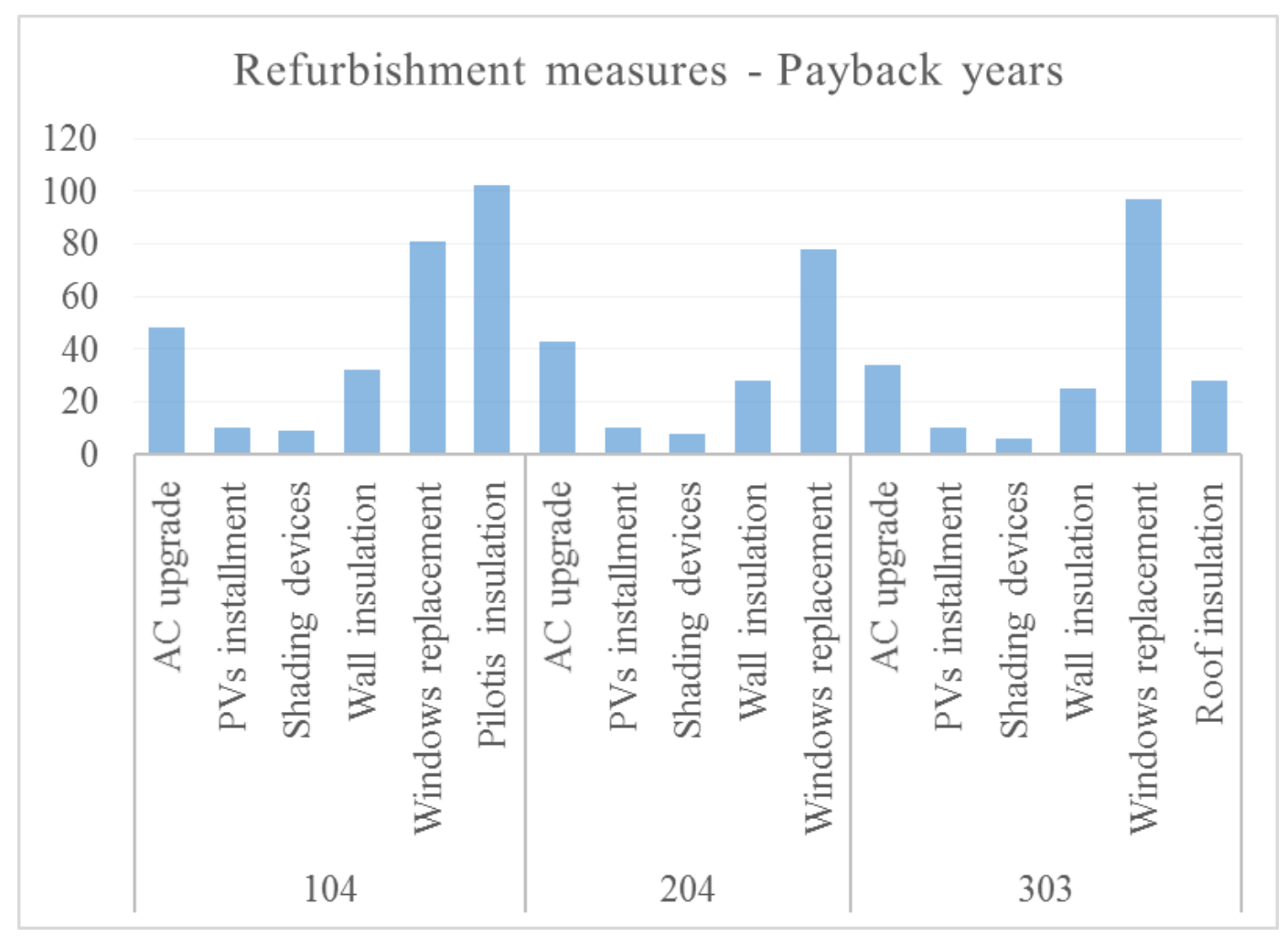

Figure 3. Cost effectiveness per refurbishment measure

\subsection{Optimised NZEB Refurbishment Scenario}

From the evaluation of the energy and cost effectiveness results of the different energy conservation measures of the building envelope, it was considered necessary to develop an alternative NZEB Scenario for the Multi-Family House, which aims in maximizing the effectiveness of the refurbishment both in terms of energy savings and payback period. The Scenario included placement of horizontal overhangs on the south-facing windows and the installment of PV panels was increased from the initial standard NZEB Scenario from 2 to 12 panels, amounting to $19.2 \mathrm{~m} 2$, which corresponds to the maximum permissible potential of $3 \mathrm{~kW}$ per dwelling [30]. The walls, the roof and the pilotis will not be further insulated and the existing double glazed windows will not be upgraded, retaining the U-values as presented on Table 2.

\subsubsection{The Optimised NZEB Scenario Energy Performance}

Using the above energy conservation measures all the apartments were raised to A EPC category (Table 6). The calculated total primary energy consumption for the optimized NZEB refurbishment scenario is reduced to 132 $\mathrm{kWh} /\left(\mathrm{m}^{2} \mathrm{a}\right)$ for the first floor, $118 \mathrm{kWh} /\left(\mathrm{m}^{2} \mathrm{a}\right)$ for the second and $135 \mathrm{kWh} /\left(\mathrm{m}^{2} \mathrm{a}\right)$ for the third. The percentage reductions in the total primary energy consumption, compared with the existing state per floor are $5 \%$ for the first 2 floors and $8 \%$ for the third floor. The corresponding percentage reductions for cooling are $18 \%$ for the first floor, $31 \%$ for the second and $27 \%$ for the third. The contribution of Renewable Energy Sources (RES), including solar thermal panels for DHW and PV panels on the roof, was $137 \mathrm{kWh} /\left(\mathrm{m}^{2} \mathrm{a}\right)$ for all the apartments, with the exception of the 3 smaller apartments (102, 105 and 202), where it reached $186 \mathrm{kWh} /\left(\mathrm{m}^{2} \mathrm{a}\right)$, since they have smaller floor area and thus higher contribution of RES per square meter. Therefore, in this Scenario, the RES cover from $94 \%$ to $174 \%$ of the primary energy consumption, resulting in production surplus of electricity and hence positive energy apartments.

\subsubsection{The Payback Period}

For the calculation of the payback period, by floor, two cases were studied. In the first case the surplus electricity produced is sold through the public grid to other consumers, whereas in the second case the excess energy production is not taken into consideration. The payback periods in the first case range from 7 (first floor) to 8 years (second and third floor) and in the latter from 8 (first floor and third floor) to 9 years (second floor). It is observed that for the third floor there is no difference in the payback years, since the surplus energy production is the minimum and therefore the economic benefit from selling the surplus electricity is negligible. 
Table 6. Energy Consumption and $\mathrm{CO}_{2}$ emissions - Optimised NZEB Refurbishment

\begin{tabular}{|c|c|c|c|c|c|c|}
\hline Housing Unit Code & $\begin{array}{l}\text { Cooling } \\
\mathrm{kWh} / \mathrm{m}^{2}\end{array}$ & $\begin{array}{l}\text { Heating } \\
\mathrm{kWh} / \mathrm{m}^{2}\end{array}$ & $\begin{array}{c}\text { Mean Consumption per } \\
\text { floor } \\
\mathrm{kWh} / \mathrm{m}^{2}\end{array}$ & $\begin{array}{c}\text { RES Primary } \\
\text { Energy } \\
\mathrm{kWh} / \mathrm{m}^{2} \\
\end{array}$ & $\begin{array}{c}\mathrm{CO}_{2} \text { emissions } \\
\mathrm{KgCO}_{2} / \mathrm{m}^{2}\end{array}$ & Energy Category \\
\hline 101 & 12.61 & 14.00 & \multirow{6}{*}{132} & 135 & -0.77 & A \\
\hline 102 & 5.62 & 11.05 & & 186 & -23.16 & A \\
\hline 103 & 5.48 & 15.60 & & 137 & -5.56 & A \\
\hline 104 & 8.37 & 14.11 & & 137 & -4.45 & A \\
\hline 105 & 32.47 & 6.78 & & 186 & -5.14 & A \\
\hline 106 & 17.97 & 11.81 & & 137 & 1.35 & A \\
\hline 201 & 4.61 & 18.153 & \multirow{5}{*}{118} & 137 & -4.23 & A \\
\hline 202 & 8.17 & 8.4576 & & 186 & -22.59 & A \\
\hline 203 & 0.78 & 20.719 & & 137 & -5.23 & A \\
\hline 204 & 10.45 & 14.158 & & 137 & -3.39 & A \\
\hline 205 & 8.37 & 12.488 & & 137 & -6.37 & A \\
\hline 301 & 8.96 & 8.9573 & \multirow{4}{*}{135} & 137 & -2.51 & A \\
\hline 302 & 15.09 & 9.9651 & & 137 & -3.18 & A \\
\hline 303 & 23.76 & 8.3799 & & 137 & 2.44 & A \\
\hline 304 & 22.76 & 7.5809 & & 137 & 1.01 & A \\
\hline Average & 12.36 & 12.15 & & 146.67 & -5.45 & \\
\hline
\end{tabular}

\section{Discussion}

The results indicate that the refurbishment of a Multi Family House constructed after 2006 (representative, existing building of this typology in Cyprus) into nearly Zero Energy Building, as defined by the Directive 366/2014, is not financially viable, with payback periods of more than 25 years, even when the money for the investment is paid immediately.

The payback period is expected to be even greater when the necessity for a loan is taken into consideration as well as the lower initial energy expenses of the households [31], thus making the standard NZEB refurbishment scenario, according the Directive 366/2014 an even less attractive option.

Based on the results obtained from the analysis of the energy and cost effectiveness of the refurbishment measures separately, an alternative refurbishment scenario was developed. This scenario incorporates the most energy efficient measures, which are the placement of horizontal overhangs above the south facing windows and the utilisation of Renewable Energy Sources with larger PV panel area. This scenario results to a payback periods of 8 to 9 years and highlights the role of PVs in the Mediterranean region. Also, taking into consideration the building as a whole, the mean reduction in the $\mathrm{CO}_{2}$ emissions was $114 \%$, compared with the existing state, achieving through the optimized NZEB Scenario an energy positive building.

The results indicate the drawbacks of the minimum requirements towards nearly Zero Energy houses, as drafted by the Cyprus government, especially for the buildings constructed after 2006. The U-values which the envelope elements must comply with, as set by the Directive, are the same for all typologies and chronological periods of houses and do not take into consideration the high cost associated with their replacement. In the case of already insulated apartments with double glazed windows, the energy conservation achieved through further insulating the dwellings and upgrading the windows is not sufficient in order to amortize in less than 10 years the associated investment. On the contrary, the placement of shading devices presents both an energy effective and economically viable choice, although not included as an obligatory measure in the requirements of the Directive 366/2014.

The shading devises could either be placed on each South facing window independently, or be considered as a unified surface and create a second façade for the building. Each option has its benefits and downsides and additional investigation is necessary in order to determine the one which best avails the current economic and aesthetic endeavors.

\section{Conclusions}

The study was carried out in order to determine the overall economic viability of the refurbishment of Multi-Family Houses, built after 2006, towards nearly Zero Energy Buildings. To this end the effectiveness of the energy conservation measures related to the upgrading of the energy performance of the envelope and the energy production (PVs) and supply systems (air-conditioning split-units) was evaluated, in terms of energy savings and cost effectiveness. Based on the results a more suitable NZEB refurbishment 
scenario is proposed.

From the study it is concluded that the most cost - effective measures for the apartments are the placement of horizontal overhangs, followed by the installment of PVs on the roof, with payback periods up to 10 years. On the contrary further insulating the envelope, replacing the windows and the air-conditioning split-units with more energy efficient ones, are proven to be uneconomical solutions.

Therefore, the cost effectiveness of the different refurbishment measures on the building envelope and the high amounts of energy produced from PV systems must be taken into consideration for the definition of the nearly zero energy buildings in Cyprus and redirect it into a more flexible and cost effective choice, in order to constitute a feasible choice of refurbishment for existing apartments, constructed after 2006.

The limitations of the study result from the use of the official energy simulation software, iSBEM_Cy, which is a non-dynamic program. Although it is obligatory to use it for issuing the Energy Performance Certificates in Cyprus and the scope of this paper was to investigate the national requirements for Nearly Zero Energy Buildings, including the issuing of an A category Performance Certificate; the software is weak for assessing with precision the energy consumption of a building.

Further studies may be directed towards using dynamic energy simulation software in order to enable diversification of the input parameters and results. These should aim to correlate the results derived from energy simulations with the actual energy consumption, as well as to evaluate the impact on the architectural quality and aesthetics of the buildings from the implementation of different refurbishment scenarios.

\section{REFERENCES}

[1] Buildings Performance Institute Europe, Europe's buildings under the microscope, A country-by-country review of the energy performance of buildings, 2011

[2] NATO Science Series, Thermal Energy Storage for Sustainable Energy Fundamentals, Case Studies and Design. Volume 234 pp. Preface ix., 2005

[3] European Commission, Online available from http://europa.eu/pol/ener/flipbook/el/files/energy_el.pdf

[4] Konstantinou, T., Knaack, U., An approach to integrate energy efficiency upgrade into refurbishment design process, applied in two case study buildings in Northern European Climate. Energy and Buildings 59, pp.301-309, 2013

[5] The Directive 2010/31/EU of the European Parliament and of the Council of 19 May 2010 on the energy performance of buildings, Official Journal of the European Union, 53, 2010.

[6] EU2020 Energy targets, Online available from http://ec.europa.eu/europe2020/pdf/themes/16_energy_and_ ghg.pdf

[7] Ministry of Energy, К.. .П. 366/2014, Online available from http://www.mcit.gov.cy/mcit/mcit.nsf/0/Directive366/2014.p df

[8] Marszal, A.J et al., Zero Energy Building - A review of definitions and calculation methodologies. Energy and Buildings, 2011

[9] D.K. Serghides, S. Dimitriou, M.C. Katafygiotou, Towards European targets by monitoring the energy profile of the Cyprus housing stock, Energy and Buildings, Volume 132, 15 November 2016, Pages 130-140

[10] IEE EPISCOPE Typology Brochure, Online available from http://episcope.eu/fileadmin/tabula/public/docs/brochure/CY _TABULA_TypologyBrochure_CUT.pdf

[11] D. K. Serghides, "Low-Energy Architecture: From Theory to Design" Renewable Energy in the Service of Mankind Vol I. Springer International Publishing, 2015. Chapter 50, Pg. 561-568.

[12] Serghides D. K., Georgakis C., The Building Envelope of Mediterranean Houses - Optimisation of Mass and Insulation. Journal of Building Physics, Volume 36 No1, ISSN: 1744-2591. Pp.83-98, 2012

[13] Morelli, M. et al., Energy retrofitting of a typical old Danish multi-family building to a "nearly-zero" energy building based on experiences from a test apartment. Energy and Buildings, 54(2012), pp.395-406, 2012

[14] Adhikari, R. S. et al., Net Zero Energy Buildings: Expense or Investment? Energy Procedia, 14, p. 1., 2012

[15] Konstantinou, T. \& Knaack, U. Refurbishment of residential buildings: A design approach to energy-efficiency upgrades. In Procedia Engineering. pp. 666-675, 2011

[16] D. K. Serghides, N. Saboohi, T. Koutra, M. C. Katafygiotou \& M. Markides, "Energy-Efficient Refurbishment of Existing Buildings: A Multiple Case Study of Terraced Family Housing." Renewable Energy in the Service of Mankind Vol I. Springer International Publishing, 2015. Chapter 49, Pg. $551-560$

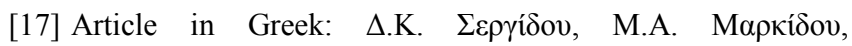

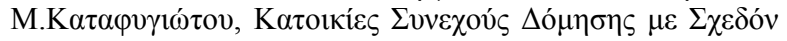

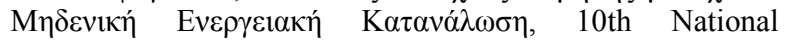
Conference for Renewable Energy Sources, 26-28 November 2014, Thessaloniki

[18] Serghides, D.K. \& Al, E., Sustainable and low energy buildings: A CASE STUDY for the Cyprus multi storey residential buildings, International Congress Energy and the Environment, 24th Scientific Conference on Energy and the Environment, Opatija, 22-24 October 2014, pp 211-214.

[19] Serghides, D., Michaelidou. K., Christofi, M., Dimitriou, S. \& Katafygiotou, M. C, "Energy Refurbishment Towards nearly Zero Energy Multi-Family Houses, for Cyprus", Sustainable Synergies from Buildings to the Urban Scale, October 2016, Thessaloniki, Greece.

[20] D. K. Serghides, M. Michaelidou, Stella Dimitriou, M. C. Katafygiotou. "Energy Refurbishment towards Nearly Zero Energy Terrace Houses for the Mediterranean Region". Mediterranean Green Buildings \& Renewable Energy, Chapter: 22, 2017 
[21] Serghides, D. K., Dimitriou, S., Katafygiotou, M. C., \& Michaelidou, M. "Energy Efficient Refurbishment towards Nearly Zero Energy Houses, for the Mediterranean Region". Energy Procedia, 83, 533-543.

[22] Typology of the building stock in Cyprus, Statistical Service of Cyprus, 2012

[23] IEE EPISCOPE Cyprus, Online available from http://episcope.eu/building-typology/country/cy/

[24] IEE EPISCOPE Project, Online available from http://episcope.eu/index.php?id=97

[25] Ministry of Energy, Cost optimal tool (software), Online available fromhttp://www.mcit.gov.cy/mcit/mcit.nsf/All/Cos t optimal tool/OpenDocument

[26] Ministry of Energy, iSBEM cy tool, Online available from http://www.mcit.gov.cy/mcit/mcit.nsf/All/E074577C58AD9 EFCC22575B60047BEA8?OpenDocument
[27] Directive 2002/91/EC of the European Parliament and of the Council of 16 December 2002 on the energy performance of buildings, Online available from http://eur-lex.europa.eu/leg al-content/EN/TXT/?uri=CELEX:32002L0091

[28] Directive К.А.П. 568/2007 Website of the Ministry of Energy, Commerce, Industry and Tourism, Online available from http://www.mcit.gov.cy/mcit/mcit.nsf/0/FBFBEE85D45A6C D5C22575D30034F1A1/\$file/KDP568_2007\%20\%20peri\% 20Apaithseon\%20Elaxistis\%20Energeiakis\%20Apodosis\%2 0Diatagma.pdf

[29] Data Hub for the energy performance of the buildings, Online available from. http://bpie.eu/uploads/lib/document/attachme nt/128/BPIE_factsheet_nNZEB_definitions_across_Europe. pdf

[30] D. K. Serghides, M. C. Katafygiotou, S. Dimitriou, IEE EPISCOPE National Progress Report - Monitoring of the Housing Stock of the Cyprus Land Development Corporation (CLDC), Online available from http://episcope.eu/monitorin g/case-studies/cy-cyprus 